\title{
Gold Nanoparticles: Synthesis and Effect on Viability of Human Non-Small Lung Cancer Cells
}

\author{
Rakesh Sharma ${ }^{*}$, Yuvraj Singh Negi² \\ ${ }^{1}$ Innovations and Solutions Amity University and Florida State University Research Foundation, Tallahassee, USA \\ ${ }^{2}$ Indian Institute of Technology Roorkee Saharanpur Campus, Saharanpur, India \\ Email: ^rksz2009@gmail.com
}

How to cite this paper: Sharma, R. and Negi, Y.S. (2021) Gold Nanoparticles: Synthesis and Effect on Viability of Human Non-Small Lung Cancer Cells. Advances in Materials Physics and Chemistry, 11, 145-153. https://doi.org/10.4236/ampc.2021.119014

Received: March 19, 2021

Accepted: September 27, 2021

Published: September 30, 2021

Copyright $\odot 2021$ by author(s) and Scientific Research Publishing Inc. This work is licensed under the Creative Commons Attribution International License (CC BY 4.0).

http://creativecommons.org/licenses/by/4.0/

(c) (i) Open Access

\begin{abstract}
Gold nanoparticles recently showed great interest for many uses including food, drug and medical applications. The algae Undaria sp. well known as wakame in South Asia are considered to be large edible brown algae. It provides nutritious source of dietary fiber, vitamin Bs and mineral. The present study aimed to investigate the use of Undaria $s p$. for green synthesis of metallic gold nanoparticles. The synthesized nanoparticles were characterized for physicochemical properties including size measurement and tested in vitro for their effect on viability of human non-small lung cancer $\mathrm{H}-460$ cell line using the MTT assay. From the results, brown algae were able to chemically form nanoparticles with chloroauric acid solution possibly due to the sulphated polysaccharides found in algae. The particle sizes were found to be approximately $10 \mathrm{~nm}$. The gold nanoparticles stabilized by the algae could decrease the cancer cell viability. However, the properties and biological activity of nanoparticles seemed to depend upon reaction time and temperature. Conclusively, gold nanoparticles synthesized and stabilized by the algae could decrease the cancer cell viability, thus indicating the potential of such nanoparticles for further study for anticancer activity.
\end{abstract}

\section{Keywords}

Brown Algae, Undaria sp., Gold Nanoparticles, MTT Assay, Non-Small Lung Cancer Cells

\section{Introduction}

Over the past few decades, nanoparticles have been explored to be used in many applications. Encapsulation of nutrients or functional ingredients using nanoparticles is commonly used in food product development [1]. For medical application, nanoparticles are employed as drug carrier especially for drug targeting. 
Due to the nanoscale size, nanoparticles provide the advantages in greater penetration in to the cell membrane, thus allowing better absorption and therapeutic effect of drug [2]. For gold nanoparticles, they are considered to be used as carriers for functional ingredients since they are non-toxic and biocompatible. Interestingly, they present anti-angiogenesis activity which could be advantageous for cancer treatment [3]. The synthesis of gold nanoparticles is unlikely to be difficult although some chemicals are required for synthesis. Recently, environmental friendly or green synthesis of gold nanoparticles is of great interest as an alternative to conventional synthesis. The natural ingredients which have been studied for their ability to synthesize the nanoparticles include polysaccharides such as chitosan [4]; however, the optimal condition of synthesis is needed to be investigated in order to ensure the stability of the nanoparticles.

Undaria sp. or wakame (in Japanese) is large edible brown seaweed originated from the north-western Pacific coast. It is rich in dietary fiber, vitamin Bs and minerals. It also contains sulphated polysaccharides which might be useful for eco-friendly synthesis of gold nanoparticles [5]. The objective of this study was to determine the use of Undaria sp. for green synthesis of metallic gold nanoparticles. The synthesized nanoparticles were characterized for physicochemical properties and tested in vitro for their effect on viability of human non-small lung cancer $\mathrm{H}-460$ cell line.

\section{Material and Methods}

For the nanoparticle synthesis, chloroauric acid $\left(\mathrm{HAuCl}_{4}\right)$ was obtained from Sigma-Aldrich (USA), and brown algae Undaria $s p$. was purchased as a commercial product from Otomegusa Company, Japan. For cell viability test, human non-small lung cancer cells (H460) was obtained from The American Type Culture Collection (ATCC), USA. Roswell Park Memorial Institute (RPMI) medium supplement with $10 \%$ fetal bovine serum was from Invitrogen (USA). L-Glutamine and antibiotics were from Invitrogen (USA). The MTT or 3-(4,5-dimethylthiazol-2-yl)-2,5-diphenyltetrazolium bromide and dimethylsulfoxide (DMSO) were supplied from Sigma-Aldrich, USA.

\subsection{Gold Nanoparticles Synthesis}

A required weight $(0.02-0.12 \mathrm{~g})$ of pulverized algae was mixed with $50 \mathrm{~mL}$ of ultrapure water. The mixture was added with $3.45 \mu \mathrm{L}$ of $1.4 \mathrm{M} \mathrm{HAuCl}_{4}$ solution. Gold nanoparticles formation was carried out at different reaction temperature $\left(25^{\circ} \mathrm{C}-80^{\circ} \mathrm{C}\right)$ and time duration $(60-120 \mathrm{~min})$ with stirring condition. The solution was then filtered using filter paper, Whatman No. 5 to remove algae particles. The final concentration of algae in formulation was $0.04 \%-0.24 \% \mathrm{w} / \mathrm{v}$. The concentration of gold ion in final solution was $0.966 \mu \mathrm{M}(20 \mathrm{ppm})$.

\subsection{Characterization of Gold Nanoparticles}

The characteristic peak of gold nanoparticle was observed using a UV-Visible spectrophotometer (UV-160A, Shimadzu, Japan). The morphology of nanopar- 
ticles was examined by using JEM-2100 Transmission Electron Microscopy (TEM) (JEOL, Japan). The gold diameter and size distribution were calculated using SemAfore software, JEOL (Japan). Energy-Dispersive X-ray spectroscopy (EDX) measurement was also studied for elemental analysis of the samples. The surface potential of gold nanoparticles was assessed using a ZEN 3600 zetasizer (Malvern Instrument, UK).

\subsection{In vitro Cell Viability Test}

The MTT assay was used to evaluate cell viability of human non-small lung H460 cancer cells. The $2 \times 10^{4} \mathrm{H}-460$ cells were grown in 96-well plate, $100 \mu \mathrm{L}$ media was added, and the cells were cultured for 24 hours at $37^{\circ} \mathrm{C}$ in a humidified $5 \% \mathrm{CO}_{2}$ atmosphere to allow cell growth. The cells were then incubated for 24 hours with either $100 \mu \mathrm{L}$ of algae-stabilized gold nanoparticles or $100 \mu \mathrm{L}$ of algae solution, while $100 \mu \mathrm{L}$ of ultrapure water was used as a control. After incubation, the culture media was discarded and the cells were washed with phosphate buffered saline (PBS). Serum-free media $(100 \mu \mathrm{l})$ was added along with 2 $\mu \mathrm{L}$ of $20 \mathrm{mg} / \mathrm{mL}$ of MTT in DMSO and the culture was incubated for another 4 hours at $37^{\circ} \mathrm{C}$. The culture media was discarded and the purple formazan was dissolved in $100 \mu \mathrm{L}$ DMSO. The UV absorbance of the sample was measured using an Anthos HT II microplate reader (Anthos Labtec Instruments) at the wavelength of $570 \mathrm{~nm}$.

\subsection{Statistical Analysis}

The percentage of cell viability was expressed as average \pm S.D. $(n=3)$ and statistically significant difference was determined using Student's t-test at p-value $\leq 0.05$.

\section{Results}

\subsection{Gold Nanoparticles Synthesis}

The algae were able to reduce the gold solution into gold nanoparticles. The appearance of rather pink solution and the UV absorbance peak of around 530 $535 \mathrm{~nm}$ represented the occurrence of gold nanoparticles [6]. It has been reported that reducing sugars and polysaccharides constituted in algae may facilitate the formation and stabilization of the gold particles [7].

The optimal condition for gold nanoparticle synthesis using wakame algae were studied in terms of algae concentration, reaction time and temperature. It was found that at higher algae concentration resulted in lower absorbance of gold nanoparticles (systems A1-A4 in Table 1). The higher in absorbance is related to an increase in a number of nanoparticles synthesized. The effect of reaction time was investigated at constant algae concentration $(0.04 \% \mathrm{w} / \mathrm{v})$ and reaction temperature of $80^{\circ} \mathrm{C}$. The result indicated the higher absorbance of gold nanoparticles with increasing time duration of reaction from 60 to $120 \mathrm{~min}$ (systems B1-B3 in Table 1). Moreover, at $0.04 \% \mathrm{w} / \mathrm{v}$ algae and reaction time of $60 \mathrm{~min}$, the absorbance of nanoparticles was greater if the reaction temperature was raised from $25^{\circ} \mathrm{C}$ to $80^{\circ} \mathrm{C}$ (systems C1-C3 in Table 1 ). 
Table 1. Variable in algae concentration, reaction time and temperature on gold nanoparticle synthesis using wakame.

\begin{tabular}{cccccc}
\hline Systems & $\begin{array}{c}\text { Algae concentration } \\
(\% \text { w/v) }\end{array}$ & $\begin{array}{c}\text { Reaction } \\
\text { time (min) })\end{array}$ & $\begin{array}{c}\text { Reaction } \\
\text { temperature }\left({ }^{\circ} \mathrm{C}\right)\end{array}$ & $\begin{array}{c}\text { Absorption } \\
\text { peak (nm) }\end{array}$ & Absorbance \\
\hline A1 & 0.04 & 60 & 80 & 533.5 & 0.195 \\
A2 & 0.08 & 60 & 80 & 532.0 & 0.171 \\
A3 & 0.16 & 60 & 80 & 534.0 & 0.123 \\
A4 & 0.24 & 60 & 80 & 533.0 & 0.118 \\
B1 & 0.04 & 60 & 80 & 533.5 & 0.195 \\
B2 & 0.04 & 80 & 80 & 533.0 & 0.203 \\
B3 & 0.04 & 120 & 80 & 533.0 & 0.207 \\
C1 & 0.04 & 60 & 25 & 533.0 & 0.111 \\
C2 & 0.04 & 60 & 60 & 533.0 & 0.177 \\
C3 & 0.04 & 60 & 80 & 533.5 & 0.195 \\
\hline
\end{tabular}

\subsection{Characterization of Gold Nanoparticles Stabilized by Algae}

The gold nanoparticles synthesized at $0.04 \% \mathrm{w} / \mathrm{v}$ algae and $80^{\circ} \mathrm{C}$ were determined for morphology by TEM analysis. The overall shape of gold nanoparticles synthesized was spherical (Figure 1). The average particle size of gold nanoparticles formed in $60 \mathrm{~min}$ was $7.85 \pm 1.43 \mathrm{~nm}$ (Figure 1), while that of 120 min was $10.15 \pm 1.96 \mathrm{~nm}$. It was found that when reaction time was increased, larger particles were formed. These results were expected since longer reaction time might allow gold nanoparticles to grow in size. The EDX spectrum of gold nanoparticles synthesized is illustrated in Figure 2. The spectrum possible indicated that the nanoparticles contained might be the gold $(\mathrm{Au})$ element based on $2.8 \mathrm{KeV}$ EDX peak and surface potential. The copper $(\mathrm{Cu})$ spectrum at $7.8 \mathrm{KeV}$ EDX peak and surface potential referred to the copper grid used in the TEM analysis. For the surface potential of nanoparticles, it was found that gold nanoparticles contained negative surface potential indicating that there were negatively charged molecules surround the particles (Table 2). It was likely that sulphated polysaccharides containing negative charges should be around the particle [8]. Hence, nanoparticles are stabilized by electrostatic repulsive force arising from the negative charges on the particle surface [9].

\subsection{Cell Viability Test}

The effect of gold nanoparticles on viability of human non-small lung H460 cancer cells was determined using MTT assay. The algae-stabilized gold nanoparticles synthesized using $0.04 \% \mathrm{w} / \mathrm{v}$ algae, $80^{\circ} \mathrm{C}$ and 120 -min reaction caused the reduction in cell viability with increasing concentration of the nanoparticles (Figure 3). The toxicity of gold nanoparticles toward the cancer cells apparently was dependent on the synthetic conditions. At the same algae concentration and reaction temperature, an increase in reaction time caused less cellular toxicity (Figure 4(a)). The non-significant differences in cell viability of nanoparticles were found when the reaction temperature was changed from $25^{\circ} \mathrm{C}$ to $80^{\circ} \mathrm{C}$ at 
120-min reaction and $0.04 \% \mathrm{w} / \mathrm{v}$ (Figure $4(\mathrm{~b})$ ). However, the nanoparticles seemed to be more toxic to the cancer cells than the corresponding algae solutions. The ability of gold nanoparticles to decrease the cell viability is considered to be arisen from the functional polysaccharides especially the sulfated-based polysaccharides in algae [10].

Table 2. Surface potential of gold nanoparticle synthesized by algae.

\begin{tabular}{ccccc}
\hline System & $\begin{array}{c}\text { Algae concentration } \\
(\% \mathrm{w} / \mathrm{v})\end{array}$ & $\begin{array}{c}\text { Reaction time } \\
(\mathrm{min})\end{array}$ & $\begin{array}{c}\text { Reaction } \\
\text { temperature }\left({ }^{\circ} \mathrm{C}\right)\end{array}$ & $\begin{array}{c}\text { Surface } \\
\text { potential }^{*}(\mathrm{mV})\end{array}$ \\
\hline $\mathrm{A} 1$ & 0.04 & 60 & 80 & $-37.6 \pm 1.54$ \\
$\mathrm{~A} 2$ & 0.08 & 60 & 80 & $-34.6 \pm 0.60$ \\
$\mathrm{~A} 3$ & 0.16 & 60 & 80 & $-33.0 \pm 0.36$ \\
$\mathrm{~A} 4$ & 0.24 & 60 & 80 & $-42.5 \pm 1.55$ \\
\hline
\end{tabular}

${ }^{*}$ mean \pm S.D. $(n=3)$.
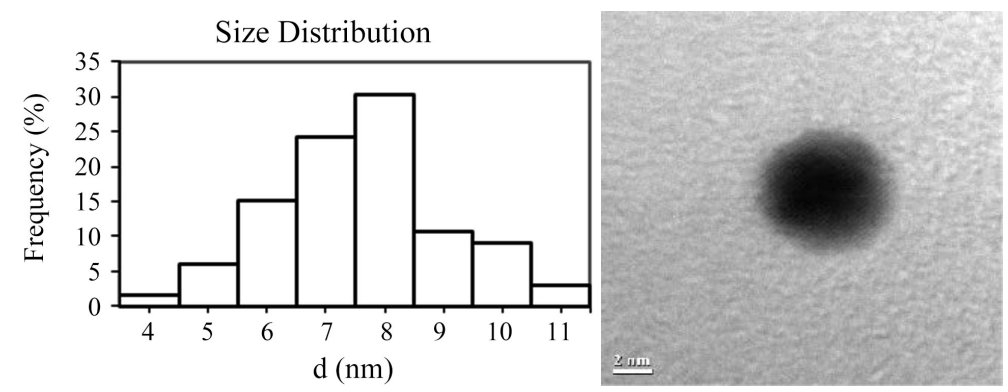

Figure 1. Size distribution (left) and morphology (right, scale bar of $2 \mathrm{~nm}$ ) of gold nanoparticles synthesized at $0.04 \% \mathrm{w} / \mathrm{v}$ algae, $80^{\circ} \mathrm{C}$ and 60 -min reaction. The average diameter (d) of nanoparticles is $7.85 \pm 1.43 \mathrm{~nm}$.

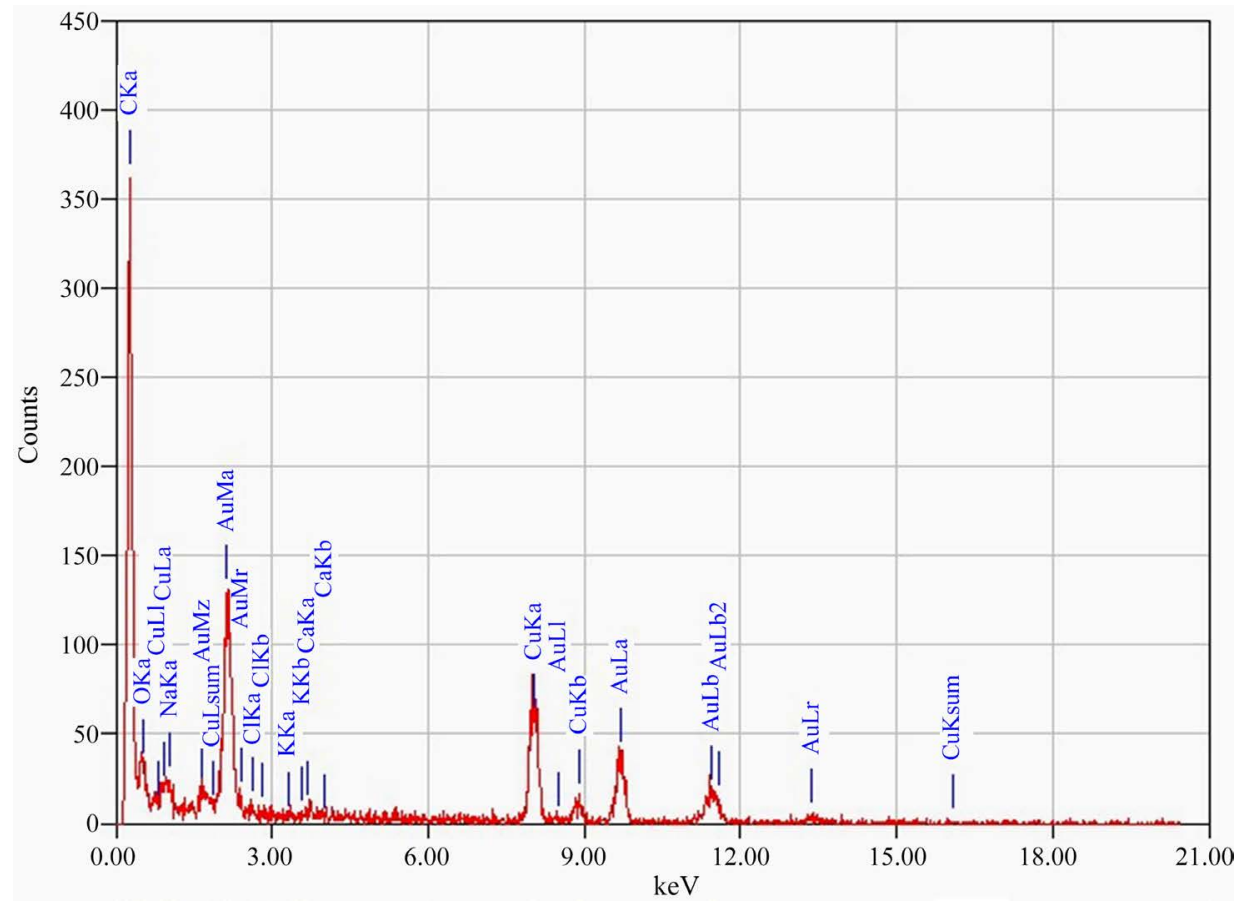

Figure 2. EDX spectrum of gold nanoparticles synthesized at $0.04 \% \mathrm{w} / \mathrm{v}$ algae, $80^{\circ} \mathrm{C}$ and 120-min reaction. 


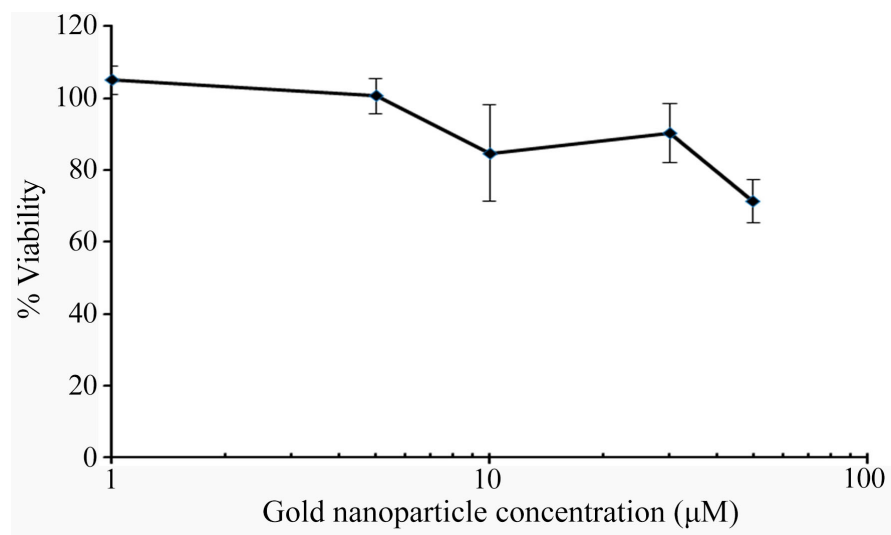

Figure 3. Cell viability after exposure to gold nanoparticles synthesized at $0.04 \% \mathrm{w} / \mathrm{v}$ algae, $80^{\circ} \mathrm{C}$ and 120 -min reaction. The values represent as mean \pm S.D. $(n=3)$.

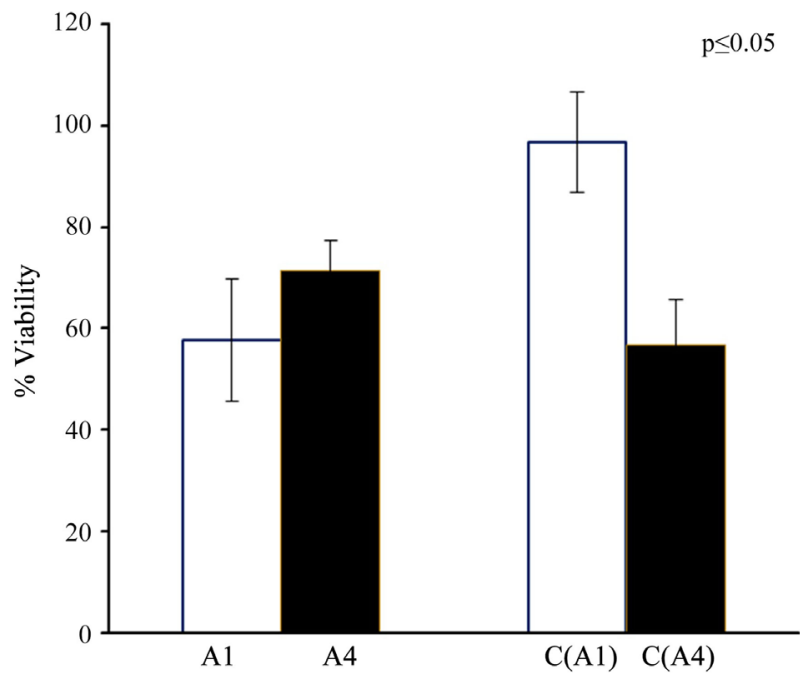

(a)

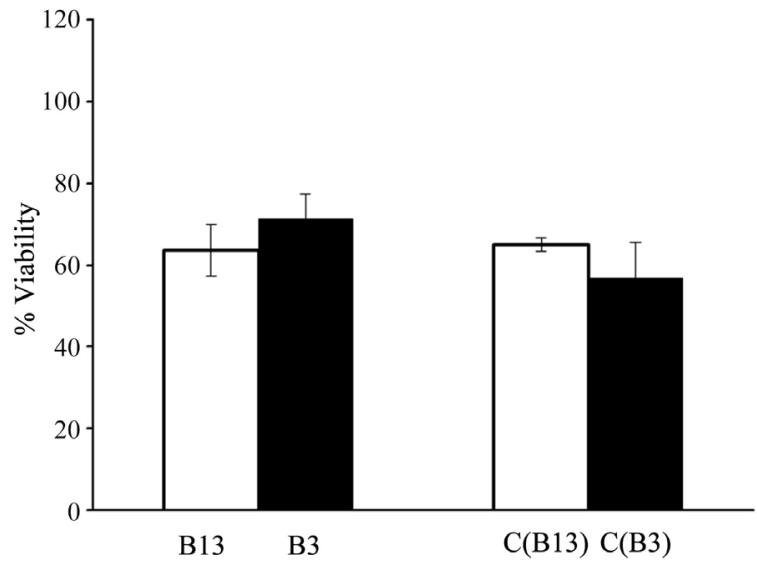

(b)

Figure 4. Cell viability (mean $\pm S$.D. of $n=3$ ) after exposure to gold nanoparticles synthesized using (a) different reaction time (A1: $60 \mathrm{~min}, \mathrm{~A} 4: 120 \mathrm{~min}$ ) at $0.04 \% \mathrm{w} / \mathrm{v}$ algae, $80^{\circ} \mathrm{C}$; and (b) different reaction temperatures $\left(\mathrm{B} 13: 25^{\circ} \mathrm{C}\right.$, B3: $80^{\circ} \mathrm{C}$ ) at $0.04 \% \mathrm{w} / \mathrm{v}, 120$-min reaction. The corresponding algae solutions were also tested and represent as $\mathrm{C}(\mathrm{A} 1), \mathrm{C}(\mathrm{A} 4), \mathrm{C}(\mathrm{B} 13)$ and $\mathrm{C}(\mathrm{B} 3)$. 


\section{Discussion}

The nanoparticle physical properties and cell toxicity characteristics usually differ and depend on the chemical method used and the biological source of organism to synthesize gold nanoparticles. Due to very slow and limited nanoparticle synthesis, microscopic TEM images with more nanoparticles could not be obtained. In our feasibility experiment, the presence of complex structure of lignan polysaccharides in algae affected the chemical synthesis of nanoparticles and possibly stabilized these gold nanoparticles. However, these claims need more investigations to justify the different morphologies of the nanoparticles synthesized with different algae contents.

The synthesized nanoparticles size was well below $15 \mathrm{~nm}$ by TEM analysis and composition was uniformly distributed high contents of gold particles by EDX analysis. Unique negative polysaccharide rich algae offered a great opportunity of negatively charged gold nanoparticle synthesis. The cell viability tests clearly exhibited the chances of gold nanoparticles to cause toxicity to cancer cells in cultures. The increased temperature and more reaction time both enhanced the cell toxicity to cancer cells in culture. However, algae cells stabilized the cell viability.

Recent reports on gold nanoparticle biosynthesis in algae, seaweeds continuously indicated the tremendous potentials with new possibility of these nanoparticles in novel uses including biotechnology, drug delivery and antibacterial potentials. Our major focus is continued use of biosynthesized gold nanioparticles in therapeutic oncology to capitalize them to arrest tumorigenesis, lesions, scars etc. by photodynamic, photothermal therapy based on concept that gold nanoparticles absorb incident photons and convert them to heat to destroy cancer cells [11]-[17]. The synthesis of gold nanoparticles is difficult from algae although selected chemicals initiated the gold nanoparticle synthesis. The major disadvantages of the current methods are that these only give evidence in expansive experiments while large scale gold synthesis from algae is inconclusive.

\section{Conclusion}

The brown algae Undaria $s p$. was able to use for preparation of gold nanoparticles. The factors influencing the synthesized nanoparticles were the algae concentration, reaction time and temperature. The algae-stabilized nanoparticles were spherical in shape with the negatively charged surface potential. The gold nanoparticles exhibited the inhibitory effect on cell viability which could imply the potential of nanoparticles for further study as carrier for anticancer purpose.

\section{Acknowledgements}

The authors gratefully acknowledge the financial support in part from Faculty of Paper and Pulp Sciences, Indian Institute of Technology Roorkee at Saharanpur campus and Amity Institute of Nanotechnology of Amity University. 


\section{Conflicts of Interest}

The authors declare no conflicts of interest regarding the publication of this paper.

\section{References}

[1] Onwulata, C.I. (2013) Microencapsulation and Functional Bioactive Foods. Journal of Food Processing and Preservation, 37, 510-532. https://doi.org/10.1111/j.1745-4549.2012.00680.x

[2] Huang, Q., Yu, H. and Ru, Q. (2010) Bioavailability and Delivery of Nutraceuticals Using Nanotechnology. Journal of Food Science, 75, 50-57. https://doi.org/10.1111/j.1750-3841.2009.01457.x

[3] Mukherjee, P., Bhattacharya, R., Wang, P., Wang, L., Basu, S., Nagy, J.A., et al. (2005) Antiangiogenic Properties of Gold Nanoparticles. Clinical Cancer Research, 11, 3530-3534. https://doi.org/10.1158/1078-0432.CCR-04-2482

[4] Huang, H. and Yang, X. (2004) Synthesis of Polysaccharide-Stabilized Gold and Silver Nanoparticles: A Green Method. Carbohydrate Research, 339, 2627-2631. https://doi.org/10.1016/j.carres.2004.08.005

[5] Hayashi, K., Nakano, T., Hashimoto, M., Kanekiyo, K. and Hayashi, T. (2008) Defensive Effects of a Fucoidan from Brown Alga Undaria pinnatifida against Herpes Simplex Virus Infection. International Immunopharmacology, 8, 109-116. https://doi.org/10.1016/j.intimp.2007.10.017

[6] Likhatskii, M.N. and Mikhlin, Y.L. (2007) Influence of Sulfide Ions on the Formation and Properties of Gold Nanoparticles in Aqueous Solutions. Glass Physics and Chemistry, 33, 422-425. https://doi.org/10.1134/S1087659607040189

[7] Singaravelu, G., Arockiamary, J.S., Kumar, V.G. and Govindaraju, K. (2007) A Novel Extracellular Synthesis of Monodisperse Gold Nanoparticles Using Marine Alga, Sargassum wightii Greville. Colloids and Surfaces B: Biointerfaces, 57, 97-101. https://doi.org/10.1016/j.colsurfb.2007.01.010

[8] Li, B., Lu, F., Wei, X. and Zhao, R. (2008) Fucoidan: Structure and Bioactivity. Molecules, 13, 1671-1695. https://doi.org/10.3390/molecules13081671

[9] Singh, R. and Lillard, J.W. (2009) Nanoparticle-Based Targeted Drug Delivery. EXperimental and Molecular Pathology, 86, 215-223.

https://doi.org/10.1016/j.yexmp.2008.12.004

[10] Jiang, Z., Okimura, T., Yokose, T., Yamasaki, Y., Yamaguchi, K. and Oda, T. (2010) Effects of Sulfated Fucan, Ascophyllan, from the Brown Alga Ascophyllum nodosum on Various Cell Lines: A Comparative Study on Ascophyllan and Fucoidan. Journal of Bioscience and Bioengineering, 110, 113-117.

https://doi.org/10.1016/j.jbiosc.2010.01.007

[11] Rajeshkumar, S., Malarkodi, C., Gnanajobitha, G., et al. (2013) Seaweed-Mediated Synthesis of Gold Nanoparticles Using Turbinaria conoides and Its Characterization. Journal of Nanostructure in Chemistry, 3, 44.

https://doi.org/10.1186/2193-8865-3-44

[12] Rajeshkumar, S., Malarkodi, C., Vanaja, M., Gnanajobitha, G., Paulkumar, K., Kannan, C. and Annadurai, G. (2013) Antibacterial Activity of Algae Mediated Synthesis of Gold Nanoparticles from Turbinaria conoides. Scholars Research Library Der Pharma Chemica, 5, 224-229.

[13] Senapati, S., Syed, A., Moeez, S., Kumar, A. and Ahmad, A. (2012) Intracellular Synthesis of Gold Nanoparticles Using Alga Tetraselmis kochinensis. Materials Letters, 79, 116-118. https://doi.org/10.1016/j.matlet.2012.04.009

[14] Oscar, F.L., Vismaya, S., Arunkumar, M., Thajuddin, N., Dhanasekaran, D. and Ni- 
thya, C. (2016) Algal Nanoparticles: Synthesis and Biotechnological Potential. In: Thajuddin, N. and Dhanasekaran, D., Eds., Algae, IntechOpen, Rijeka, Chapter 7.

[15] Khanna, P., Kaur, A. and Goyal, D. (2019) Algae-Based Metallic Nanoparticles: Synthesis, Characterization and Applications. The Journal of Microbiological Methods, 163, Article ID: 105656. https://doi.org/10.1016/j.mimet.2019.105656

[16] Sengani, M., Grumezescu, A.M. and Rajeswari, V.D. (2017) Recent Trends and Methodologies in Gold Nanoparticle Synthesis-A Prospective Review on Drug Delivery Aspect. Open Nano, 2, 37-46. https://doi.org/10.1016/j.onano.2017.07.001

[17] Rajasulochana, P., Dhamotharan, R., Murugakoothan, P., Murugeshan, S. and Krishnamoorthy, P. (2010) Biosynthesis and Characterization of Gold Nanoparticles Using the Alga Kappphycus alvarezii. International Journal of Nanoscience, 9 , 511-516. https://doi.org/10.1142/S0219581X10007149 